\title{
Competentiegericht onderwijs en toetsen
}

Citation for published version (APA):

Heeneman, S. (2014). Competentiegericht onderwijs en toetsen: ballast of bagage? Maastricht University. https://doi.org/10.26481/spe.20140919sh

Document status and date:

Published: 19/09/2014

DOI:

10.26481/spe.20140919sh

Document Version:

Publisher's PDF, also known as Version of record

\section{Please check the document version of this publication:}

- A submitted manuscript is the version of the article upon submission and before peer-review. There can be important differences between the submitted version and the official published version of record.

People interested in the research are advised to contact the author for the final version of the publication, or visit the DOI to the publisher's website.

- The final author version and the galley proof are versions of the publication after peer review.

- The final published version features the final layout of the paper including the volume, issue and page numbers.

Link to publication

\footnotetext{
General rights rights.

- You may freely distribute the URL identifying the publication in the public portal. please follow below link for the End User Agreement:

www.umlib.nl/taverne-license

Take down policy

If you believe that this document breaches copyright please contact us at:

repository@maastrichtuniversity.nl

providing details and we will investigate your claim.
}

Copyright and moral rights for the publications made accessible in the public portal are retained by the authors and/or other copyright owners and it is a condition of accessing publications that users recognise and abide by the legal requirements associated with these

- Users may download and print one copy of any publication from the public portal for the purpose of private study or research.

- You may not further distribute the material or use it for any profit-making activity or commercial gain

If the publication is distributed under the terms of Article $25 \mathrm{fa}$ of the Dutch Copyright Act, indicated by the "Taverne" license above, 
Prof. dr. Sylvia Heeneman

Faculty of Health, Medicine and Life Sciences

\section{Competentiegericht onderwijs en toetsen: Ballast of bagage?}




\section{Competentiegericht onderwijs en toetsen: Ballast of bagage?}

I naugurele rede

Maastricht, 19 september 2014

Faculty of Health, Medicine and Life Sciences

Prof. dr. Sylvia Heeneman 


\title{
Competentiegericht onderwijs en toetsen, ballast of bagage?
}

\author{
Geachte Pro-rector, Raad van Bestuur en College van Toezicht, \\ beste collega's en studenten, \\ lieve familie en vrienden,
}

Hartelijk dank voor Uw komst en het bijwonen van mijn inaugurale rede.

Voor wie niet dagelijks met onderwijs bezig is, is het begrip competentie misschien onbekend of vaag. Voor wie betrokken is bij onderwijs als opleider, docent of student is het een onderdeel van de onderwijspraktijk, soms zijdelings, en soms is er niet omheen te komen. De titel van mijn oratie : Competentiegericht onderwijs en toetsen, ballast of bagage?' laat ook een tweedeling zien. Zoals wel vaker met tegengestelde begrippen is het nooit zwart-wit en dat zal ook in deze rede naar voren komen. Zoals uit de titel ook blijkt zal ik het in deze oratie niet hebben over mijn andere werkgebied, het cardiovasculair onderzoek. Ik ben opgeleid als biomedisch onderzoeker en heb het cardiovasculair onderzoek steeds met plezier gecombineerd met het geven van onderwijs, en de laatste jaren steeds intensiever met het organiseren en ontwikkelen van onderwijs en leren zoals dat in deze Faculteit plaatsvindt. De Faculteit heeft een Carrièrebeleid Onderwijs, waarin stafleden die onderzoek en onderwijs combineren de mogelijkheid wordt geboden zich op het terrein van onderwijs verder te ontwikkelen. Ik ben de Faculteit dankbaar voor dit initiatief en het carrièreperspectief zoals uitgewerkt in de nota Carrièrebeleid Onderwijs. Dit biedt een horizon voor blijvende ontwikkeling voor collegae die dagelijks met enthousiasme bezig zijn met het geven, organiseren en ontwikkelen van onderwijs op de werkvloer.

Terug naar het onderwerp: ik zal in deze rede ingaan op het competentiegericht opleiden en toetsen in het hoger onderwijs. I k zal dit illustreren met voorbeelden van onderwijs in de praktijk en onderzoek van onderwijs. De opbouw van mijn rede is als volgt:

In het eerste deel zal ik het begrip competentie, definitie en onderliggende leertheorieën nader toelichten, gevolgd door (tweede deel) het beantwoorden van de vraag, wanneer en waarom is competentiegericht onderwijs geïntroduceerd? In het derde deel zal ik ingaan op het toetsen van competenties. In het vierde deel zal ik vooruitblikken op de toekomst van competentiegericht opleiden en toetsen in de Geneeskunde opleiding (in een volgend Raamplan). In het vijfde deel zal ik ingaan op competentiegericht opleiden en toetsen in andere opleidingen van de Faculteit. De rede sluit ik af met een korte reflectie en dankwoord. 


\section{Deel 1: Het begrip competentie, definitie en onderliggende leertheorieën}

Als het begrip competentie wordt opgezocht in het van Dale woordenboek van de Nederlandse taal, staat daar 'bevoegdheid'. In 2002 hebben van Merriënboer, van der Klink en Hendriks in opdracht van de Onderwijsraad een studie uitgevoerd over de conceptuele verheldering van het begrip competentie en onderzocht of een harmonisatie van het competentiebegrip tot de mogelijkheden behoort. Uit dit zeer uitgebreide en gedegen rapport blijkt dat er veel definities in omloop zijn en die verschillen door de perspectieven van waaruit de definities ontwikkeld zijn. Zo verschilt de invulling per land, het doel waarvoor de definitie wordt gebruikt, en een andere belangrijke factor is het onderliggende leertheoretische kader [1].

Ik ga dit laatste verder uitleggen omdat de onderliggende leertheorie belangrijk is voor vormgeving en toetsing van onderwijs in het algemeen en van competentiegericht onderwijs.

Wat is een leertheorie? Leertheorieën zijn psychologische theorieën over de manier waarop mensen verbanden leggen tussen stimuli, en hoe ze leren van ervaringen. Er zijn een aantal stromingen, waarvan ik er 2 hier toelicht:

Als eerste het behaviorisme, hierin is het uitgangspunt dat een bepaalde stimulus zorgt voor een respons, deze respons is zichtbaar en waarneembaar in gedrag. De reactie op een stimulus wordt gezien als een soort reflex, er is weinig of geen vrije wil aanwezig in hoe gereageerd wordt $[2,3]$. Bekrachtiging is een belangrijk onderdeel van deze leertheorie, bij positieve bekrachtiging wordt het gedrag dat je laat zien geprezen, je krijgt een beloning of een goed cijfer. Een volgende keer zal hetzelfde gedrag getoond worden bij die stimulus, dat leidde immers tot een beloning. Een bekend voorbeeld is de koppeling van de productie van speeksel aan een belletje, het dier zal leren dat het rinkelen van het belletje gekoppeld is aan voedsel, en zal reageren door speeksel te produceren bij het rinkelen van het belletje, ook als er geen voedsel is. In het onderwijs ligt de focus op de presentatie van het doel dat moet bereikt worden, welke stimulus leidt tot een goede reactie [2, 3]. Als illustratie een quote van Skinner, een beroemde onderzoeker van deze leertheorie : "forget sophisticated learning systems - just train the students with reward systems until they do what you want". Kort samengevat Behaviorisme is "Leren door te reageren".

In het behaviorisime heeft de lerende zelf weinig in te brengen, in het onderwijs staat doceren van kennis centraal en niet het leren van de 
student zelf $[2,3]$. In het constructivisme verandert de focus van passieve overdracht van kennis en routines in het onderwijs naar actieve toepassing van kennis op problemen [2,3]. Constructivisten zijn van mening dat studenten niet de kennis van de externe wereld in hun geheugen laden of laten laden, maar dat studenten een eigen interpretatie en perspectief van de wereld hebben en dat baseren op individuele ervaringen en interacties met anderen. In het onderwijs is de lerende of student een actieve deelnemer. Het onderwijs is er opgericht om de student te laten zien hoe zij hun kennis en vaardigheden betekenis kunnen geven en hoe zij dit kunnen onderzoeken, zelf sturen en evalueren. Hierbij een quote van Albert Einstein: "I never teach my pupils, I only create the conditions in which they learn". Constructivisme: Leren door zelfsturen.

Voor de definitie van competentie en competentiegericht onderwijs is de stelling van de leertheorie belangrijk. Gaat het om eigenschappen en vaardigheden die geobserveerd en objectief gemeten moeten worden, in lijn van het behaviorisme, of maken de eigen interpretaties en zelfsturing deel uit van de competenties, zoals in de constructivistische benadering [4].

In het rapport van de Onderwijsraad worden een aantal criteria voorgesteld waaraan een definitie voor competentie moet voldoen, waaronder

- gebondenheid aan een context,

- als een cluster van vaardigheden, kennis, inzichten en houding, en

- de mogelijkheid tot ontwikkeling van competentie in de tijd [1].

Samenvattend, de definitie van het begrip competentie is niet eenvoudig, er zijn wel criteria voor aan te geven. In het dagelijks gebruik wordt het vaker benoemd als een combinatie van kennis, vaardigheden en houding. In de van Dale is 'bekwaamheid' mogelijk een betere omschrijving dan 'bevoegdheid'.

\section{Deel 2: Wanneer en waarom is competentiegericht onderwijs geïntroduceerd?}

In de jaren 60 was er in het beroepsonderwijs een omslag zichtbaar van theoretisch onderwijs naar competentiegericht onderwijs. Veel werkgevers waren namelijk niet meer tevreden over het niveau van de schoolverlater en de startende werknemer. Deze waren theoretisch goed opgeleid, maar hadden moeite om de kennis toe te passen in de praktijk. Het onderwijs was met name gericht op kennisverwerving en theorie en de relatie met het toekomstige beroep was niet duidelijk. Er was behoefte aan meer 
connectie tussen uitkomsten van het onderwijs en de vaardigheden die werkgevers nodig hadden. Het woord 'uitkomst' is hier belangrijk [5, 6]. Er kwam meer aandacht voor leren op de werkplek waar de uitkomst van de opleiding duidelijk zichtbaar gemaakt kan worden, en het ontwikkelen van vaardigheden om te blijven leren en kunnen inspelen op veranderingen in het beroepsveld, ook na afsluiting van de beroepsopleiding, het zogenaamde 'levenslang leren' $[1,6]$. Om goed te functioneren moeten werknemers vandaag de dag kritisch kunnen nadenken, creatieve oplossingen kunnen verzinnen, om kunnen gaan met veranderingen in de maatschappij en technologie, en goed kunnen samenwerken. Deze vaardigheden zijn heel duidelijk het doel van het constructivistische competentiegericht opleiden [1,7]. Met deze verandering werd ook de focus verlegd van een opleiding waar de tijd die de opleiding duurt bepalend is, met andere woorden, van het uitgangspunt: een opleiding duurt 6 jaar en na 6 jaar is men klaar, naar een uitgangspunt met een focus op wat de uitkomst is en wat geleerd is.

Er waren ook kritieken. Zoals ik net toelichtte waarom competenties hun intrede deden in het onderwijs, zijn er ook sceptici die de vraag stelden, als competenties het antwoord zijn, wat was eigenlijk het probleem? Er is nog weinig onderzoek of onderwijs dat gericht is op uitkomsten daadwerkelijk het leren verbeterd [5]. Er is een gevaar voor detaillisme,er is neiging om competenties op te delen in subcompetenties, en daaronder ook weer uitwerkingen, dit kan leiden tot lange lijsten van competenties en subcompetenties. Als deze allemaal in het onderwijs minutieus worden uitgewerkt, en gevangen op afvinklijsten, dreigt een reductionistische aanpak die het competentieraamwerk tekort doet [8]. Andere kritiek was dat sommige vaardigheden of houdingen moeilijk in competenties of uitkomsten te vertalen zijn, zoals professioneel gedrag of humanisme [9]. Critici stelde dat competenties geen meetbare constructen zijn en dus niet getoetst kunnen worden [10]. Verder kan het definiëren van een 'uitkomst' een meer of mindere mate van standaardisering tot gevolg hebben, maar in het onderwijs is ook behoefte aan individualisering, en zeker als een student in een constructivistische leeromgeving zijn leren en traject zelf stuurt en keuzes wil en moet kunnen maken.

Samengevat zijn er voor en tegenstanders, Ballast en Bagage: Mijn conclusie is dat de verandering van focus naar het werken aan ontwikkeling van 'competentie' en het continue traject van zelfsturend leren, een groot en belangrijk winstpunt is ten opzichte van 'gewoon de tijd uitzitten die ervoor staat'. De uitdagingen liggen in het strategisch benutten van tijd en geld en het maximaliseren van de voordelen, terwijl 
voorkomen wordt dat een onderwijs programma gebaseerd op competenties een administratieve olifant wordt [11].

De verschuiving naar een onderwijsomgeving waar competenties meer en meer centraal komen te staan, gebeurde in Nederland parallel aan veranderingen in de opbouw en onderwijsfilosofie van de Geneeskunde opleiding. De basis van de Geneeskunde opleiding veranderde van een kennisgericht Academisch Statuut in de jaren 60 tot een competentiegericht opleidingsplan, of Raamplan 2009 [12].

Deze verandering kan geschetst worden aan de hand van de piramide van Miller [13]. Miller introduceerde in 1990 een piramide met niveaus van bekwaamheid in de context van de medische opleiding. Het is belangrijk te realiseren dat bij een piramide de onderste niveaus altijd de basis of het fundament zijn voor de bovenliggende lagen.

Dit is de piramide (Figuur 1), de lagen zijn "weten, weten hoe, laten zien en doen".

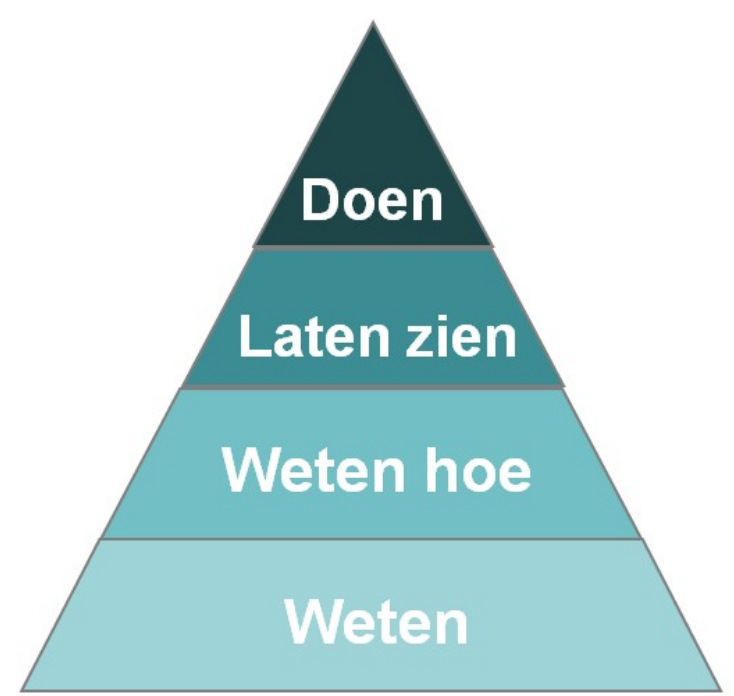

Figuur 1: Piramide van Miller [13]

Het onderste niveau is 'weten', of kennis: kennis was de basis van het Geneeskunde curriculum in de jaren 60-70. Theorie en praktijk waren ver van elkaar verwijderd.

De volgende laag is 'weten hoe': hoe kan de kennis gebruikt worden bij het oplossen van probleemtaken. In het onderwijs kwam deze omslag van focus op alleen kennis naar toepassing einde jaren 60, de huisartsen klaagden dat de studenten onvoldoende voorbereid waren voor de huisartspraktijk. Dit leidde tot een lichte mate van integratie van kennis en praktijk onderwijs, wat werd uitgewerkt in het opleidingsplan of Raamplan 1974 [14]. Een belangrijke verandering in het onderwijs was ook dat het leren van de student centraler kwam te staan en dit werd meer en meer het uitgangspunt van hoe het onderwijs werd 
vormgegeven. In Maastricht startte in 1974 de opleiding Geneeskunde en hier was het onderwijs vanaf het begin studentgecentreerd en vorm gegeven met een constructivistische onderwijsvorm: het probleemgestuurd onderwijs.

In de jaren 80 en 90 kwam het vaardighedenonderwijs centraler te staan, het 'laten zien' werd belangrijk. Het onderwijs werd meer en meer ingericht met patiëntproblemen als startpunt, er kwam parallel onderwijs voor communicatieve vaardigheden, professionele en wetenschappelijke vorming. In het Raamplan 1994 [15] werd een 'eindproduct' gedefinieerd, namelijk het profiel van de arts aan het einde van de artsopleiding. Dit gaat toe naar de top van de piramide, het 'doen', de student kan de, in de opleiding opgedane kennis, vaardigheden en houdingen toepassen in een authentieke, complexe, dagelijkse praktijk situatie. Het onderwijs vond meer en meer plaats in de klinisch praktijk.

In het Raamplan 1994 werden al een aantal zaken genoemd die net aan de orde zijn geweest bij de uitleg van het begrip competentie, namelijk eindproduct, niveau en mix van kennis, vaardigheden en houding. De aanzet in het Raamplan 1994, werden doorgezet in het Raamplan 2001 [16] en 2009 [17]. Er werd een grootschalige vernieuwing ingezet om de opleiding competentiegericht te maken. De inspiratie was het CanMEDS model, de Canadian Medical Education Directions for Specialists uit 2005 [18], een in Canada ontwikkeld competentieprofiel voor de medischspecialistische vervolgopleidingen. Hierin werden de competenties beschreven als rollen die de arts gebruikt in de behandeling van de patiënt, bv de arts als samenwerker, de arts als gezondheidbevorderaar en de arts als medisch expert. De aandacht in het onderwijs verschoof naar competentiegericht opleiden met het leerproces van de student als centrale component. De CanMEDS waren de basis voor het Raamplan 2009, waarin het profiel van de arts wordt beschreven in rollen of competenties [17]. Dit zijn de competenties van het Raamplan 2009 (Figuur 2). De competentie medische expert in het centrum van deze rozet, omringt door competenties of rollen als samenwerker, communicator academicus.

In de Geneeskunde opleiding van vandaag de dag heeft het Raamplan 2009 en de 7 competenties een centrale rol in de geneeskunde curricula en vervolgopleidingen. 


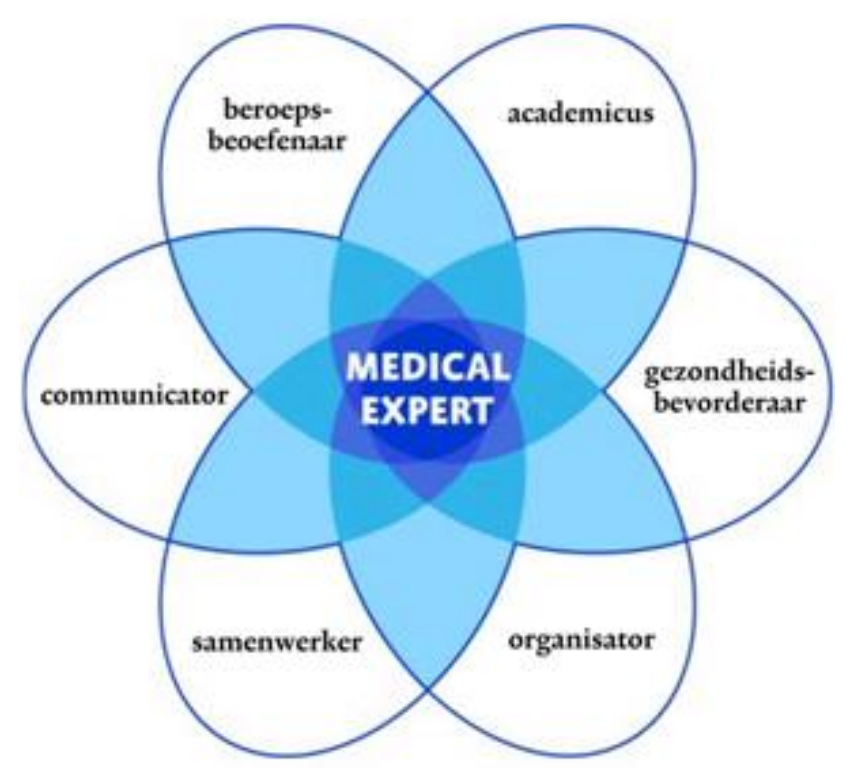

Figuur 2: De 7 (CanMEDS) competenties van het Raamplan 2009 [17]

\section{Deel 3: Toetsing van competenties}

Met de competenties centraal in de opleiding, hoe staat het met de toetsing? In de onderwijspraktijk blijkt dat er een duidelijke relatie moet zijn tussen onderwijs en toetsing. Dit wordt ook wel 'Constructive Alignment' genoemd: Een duidelijke relatie of driehoek tussen leer-en onderwijs activiteiten, toetsactiviteiten en beoogde leerdoelen of leerresultaten [19]. I $\mathrm{k}$ zal in dit deel toelichten dat een curriculum dat gebaseerd is op constructivistisch onderwijs, maar enkel getoetst wordt met gestandaardiseerde meerkeuzetoetsen, niet tot de gewenste leerresultaten zal leiden.

Wat meten we eigenlijk in een toets? Meet de toets echt iets of kan er net zo goed worden gedobbeld om uitspraken te doen over studenten? Is de toets betrouwbaar? In principe kan 'betrouwbaarheid' bekeken worden met een $2^{\mathrm{e}}$ toets, scoren studenten dan hetzelfde? Dit is in de praktijk moeilijk te realiseren omdat studenten leren van het maken van een toets. Het kan wel berekend worden door iedere vraag van de toets te beschouwen als een deeltoets [20]. Met behulp van statistische programma's kan vervolgens een betrouwbaarheidsmaat uitgerekend worden.

Een toets is maximaal betrouwbaar bij 1 , en onbetrouwbaar bij 0 . Op de werkvloer wordt uitgegaan dat een betrouwbaarheid van $0.8-0.9$ acceptabel is. Hierbij moeten we ons realiseren dat bij een betrouwbaarheid van 0.8 (of $80 \%$ ) er $20 \%$ onzekere beslissingen worden genomen. Als we uitgaan van de klassieke 6.0 als grens voor wel of niet 
halen van een specifieke toets, is de student met een 5.8 dan ook geslaagd? Door een zekere onbetrouwbaarheid kunnen we hier nooit $100 \%$ zeker van zijn. Het onbetrouwbaarheid interval is rondom de 5.8 best groot, tussen de 4.8 en 6.8 en deze student had, gegeven de betrouwbaarheid ook aan de andere kant van de streep had kunnen zitten en andersom hetzelfde voor de student met de 6.1. En houdt hierbij in het achterhoofd dat er veel kan afhangen van deze beslissing.

Wat is het doel van toetsing behalve 'meten', d.w.z. vaststellen of een student aan de maat is of niet. In wat deze jongen van 10 zegt zit een kern van waarheid: het doel van toetsen is ook feedback voor de docent over het onderwijsprogramma en ook zal toetsen het leren van de studenten stimuleren en sturen.

Toetsen waarbij het resultaat gekoppeld is aan een zak-slaagbeslissing worden ook wel summatief genoemd, het eindresultaat 'telt' en bepaalt of een onderwijsonderdeel behaald is, afgesloten kan worden met studiepunten. Toetsen, of andere vormen van evaluaties, zoals feedback waaraan geen zak-slaag beslissing verbonden zijn, die informatie geven over de prestatie, worden 'formatief' genoemd. De meeste klassieke toetsen aan het einde van een studieonderdeel of periode zijn summatief. Doel van de toets is vast te stellen of de student voldoende heeft geleerd. Voor studenten is het begrijpelijk dat zij gefocust zijn op het 'halen' van minimaal een 6 , of zo uit te komen dat het gemiddelde van verschillende toetsonderdelen een 6 is. Immers 'zakken' betekent overdoen, extra werk, mogelijk vertraging. Voor studenten zijn de toetsen een belangrijke, misschien soms wel de belangrijkste stimulans tot leren [21, 22]. De uitdaging van onderwijsmakers en docenten is om toetsing zodanig in te zetten dat leren wordt gestimuleerd en dat studenten toetsen niet alleen maar zien als een hoepel waar succesvol doorheen gesprongen moet worden. Maar liever als een leermoment.

Hoe werkt dit dan voor het toetsen van competenties?

Zoals U nu weet gaat het er bij competentiegericht onderwijs om het integreren van kennis, vaardigheden en houdingen en het kunnen toepassen hiervan in beroepsrelevante situaties. Dit vraagt om een andere wijze van toetsen en beoordelen. En ook belangrijk, gezien de complexiteit van competenties zal er een diversiteit aan toetsvormen nodig zijn, er is niet 1 toetsvorm waarmee competenties getoetst kunnen worden [23].

Dit kan goed worden uitgelegd aan de hand van de piramide van Miller. In herinnering, de lagen waren "weten, weten hoe, laten zien en doen". 
Het niveau 'weten' kan bijvoorbeeld getoetst worden met een schriftelijke meerkeuze-antwoord toets.

Het volgende niveau 'weten hoe' kan getoetst worden met schriftelijke casus of meer toegepaste (inzicht) meerkeuze-antwoord toetsen.

Het niveau 'laten zien' kan getoetst worden met een vaardigheidstoets met een simulatie patiënt, de student stelt een diagnose en stelt een beleid op, en dit wordt beoordeeld. De top 'doen' wordt getoetst in de beroepspraktijk, en wordt ook wel werkplekbeoordeling genoemd [23]. Bij de top van de piramide staat als toetsvorm het portfolio. Het portfolio is een instrument waarin toets en feedback informatie kan worden verzameld, de student gebruikt dit om na te gaan waar hij of zij staat, wat gaat goed, wat kan beter, en daarmee het opvolgen en bewaken van competentieontwikkeling en het stellen van leerdoelen om zich verder te ontwikkelen [24-27]. Ik kom zo terug op het portfolio als instrument in het toetsen van competenties.

Er is dus een diversiteit aan toetsvormen nodig om alle lagen van de piramide en competenties te kunnen toetsen. Hoe te toetsen in een competentiegerichte opleiding? I k heb aangegeven dat veel toetsen gericht zijn op een gedragsmatige, behavioristische filosofie; elke individuele toets is een zak-slaag beslissing en een hoepel die genomen wordt. Het komt nog vaak voor dat een constructivistische leeromgeving, zoals in het probleem-gestuurd onderwijs, gecombineerd worden met behavioristische toetsen om vast te stellen of een student genoeg geleerd heeft. Deze toetsen zullen het leren van de studenten sturen, op een ongewenste manier, er is geen 'alignment'. Dit kan geïllustreerd worden met de vraag: 'moeten we dit weten voor de toets' en dit in een omgeving waar probleemgestuurd en zelf-gestuurd leren de basis zou moeten zijn van het curriculum.

Dus meer constructivistisch en minder behavioristisch toetsen, hoe kan dat bewerkstelligd worden? Een mogelijke aanpak is het combineren van toets en feedback informatie in een programma van toetsen, zoals ontworpen door collegae Prof Dr Cees van de Vleuten en Prof Dr Lambert Schuwirth [28-31]. Hun model van programmatisch toetsen gaat uit van een sterke verbondenheid tussen onderwijs en toetsing. De toetsing sluit maximaal aan bij het onderwijs, qua vorm en hoe vaak getoetst wordt en heeft een zinvolle betekenis voor het leren door het geven van goede, beschrijvende informatie of feedback over wat goed ging, misconcepties, fouten en wat beter kan. Gedurende het hele jaar zijn er bloktoetsen, vaardigheidstoetsen, voortgangstoetsen, opdrachten, feedback van medestudenten in de onderwijsgroep, tijdens een groepsopdracht. Merendeel van de toetsen of opdrachten geeft informatie en feedback en 
is in principe geen beslismoment. Elke toets heeft zoals net uitgelegd, een bepaalde mate van betrouwbaarheid, net als feedback een bepaalde mate van subjectiviteit heeft, maar omdat verschillende vormen van toetsen gebruikt worden en meerdere beoordelaars en feedbackgevers betrokken zijn in dit proces, geeft de veelheid aan informatie een betrouwbare weergave van hoe iemand functioneert qua kennis, vaardigheden en houding. Voor sommige leeractiviteiten of leertaken staat er meer op het spel, bv een bepaalde vaardigheid die beheerst moet worden, voor studenten biomedische wetenschappen is dat het ijken van een $\mathrm{pH}$ meter, voor geneeskunde studenten is dat bv injecteren of bloeddruk meten. Grote beslissingen worden gebaseerd op een veelheid en diversiteit van informatie. Zo kan de overgang naar een volgend academisch jaar gekoppeld zijn aan een beslissing op basis van alle verzamelde informatie, zowel kwantitatief als kwalitatief [30]. Op deze dia (Figuur 3) staat de relatie tussen de verschillende toets- en evaluatie-instrumenten en de competenties: Dit is de situatie waarbij de relatie tussen de competenties en toets- informatie 1 op 1 is, zoals hier weergegeven met de pijlen (Figuur 3A), 1 toets of evaluatie-instrument wordt gebruikt voor 1 competentie, maar, in programmatisch toetsen geven meerdere instrumenten informatie over een competentie (Figuur 3B) [32]. De relatie tussen competentie en toetsinstrumenten verschuift van ' 1 staat tot 1 ' naar ' $\mathrm{n}$ staat tot $\mathrm{n}$ '.
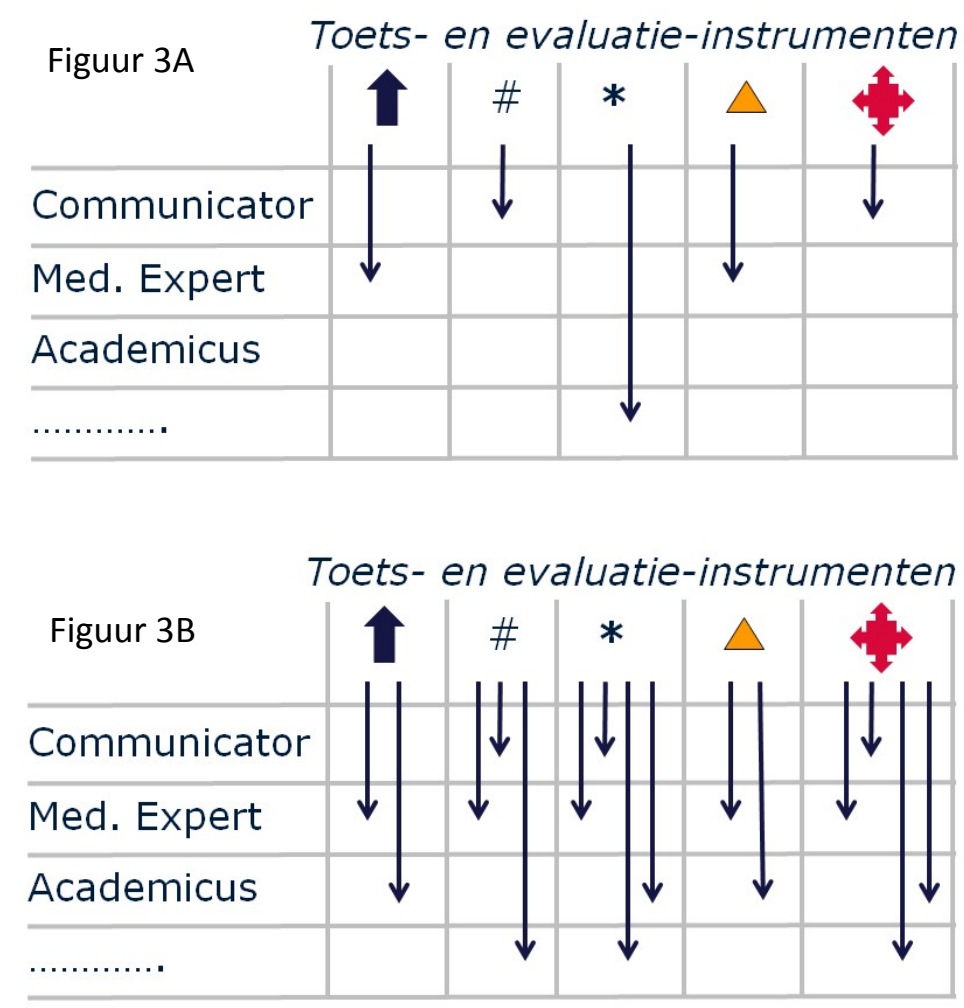

Figuur 3: Relatie tussen competenties en toets-, en evaluatieinstrumenten 
Een programma van toetsen, hoe kan dat eruit zien in een competentiegerichte opleiding?

Een korte uitstap naar de praktijk: Op deze dia (Figuur 4) is de opbouw van de medische basisopleiding in Nederland te zien. Het geneeskunde curriculum bestaat uit een 3 jarige Bachelor en 3 jarige Master opleiding. Sinds 2006 zijn er ook mogelijkheden om na een biomedische bachelor een zogenaamd 'graduate-entry' Masterprogramma Geneeskunde te volgen. In Maastricht heeft dit vorm gekregen in de Research master opleiding Arts-Klinisch Onderzoeker, afgekort A-KO, waarin studenten worden opgeleid tot arts en klinisch onderzoeker.

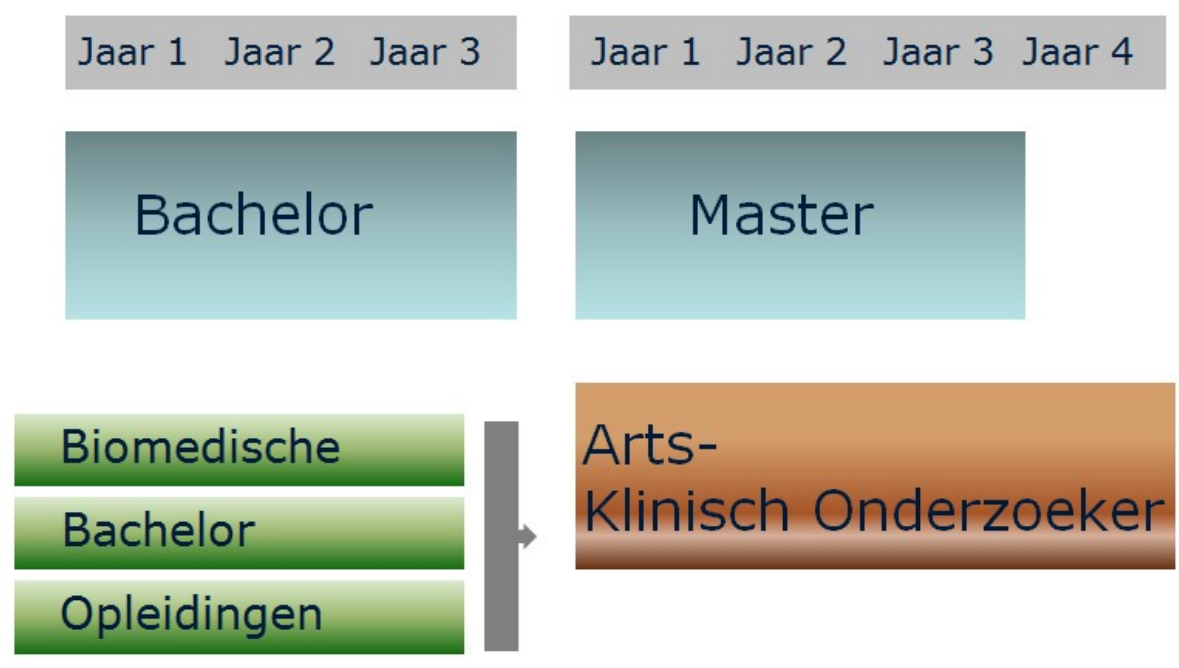

Figuur 4: Opbouw medische basisopleiding Geneeskunde

Het A-KO Curriculum is gebouwd in 2005-2006, samen met Prof dr Ton de Goeij, Prof dr Mirjam oude Egbrink, en Prof dr Luc Snoeckx. De eindtermen/ of leeruitkomsten waren gedefinieerd op basis van het toenmalige raamplan 2001 en specifieke eindtermen voor het klinisch onderzoek programma. De $1^{\text {ste }}$ studenten zijn begonnen in 2007 . Er is verdeling in het curriculum in pre-klinisch, probleem-gestuurd onderwijs in jaar 1 en 2, vergelijkbaar met het Bachelor curriculum Geneeskunde en klinisch, praktijkgericht onderwijs in jaar 3 en 4, vergelijkbaar met het Master Geneeskunde curriculum, met parallel onderwijsactiviteiten voor het klinisch Onderzoeker onderwijs. Het A-KO curriculum en het programma van toetsen is vanaf 2010 aan de hand van de 7 competenties uit het Raamplan 2009 vormgegeven.

In de A-KO opleiding hebben wij geprobeerd de theorie van programmatisch toetsen in de praktijk te brengen. In de A-KO opleiding geeft het onderwijsprogramma veel en gevarieerde informatie in de vorm 
van toetsen, evaluaties en feedback, alle informatie wordt verzameld in een portfolio. Onderliggende principes zijn dat de individuele toetsen niet leiden tot zak-slaag beslissingen, er zijn geen ECTS of studiepunten verbonden aan blokken of opdrachten. Studenten gebruiken de informatie van de toetsen en feedback om kritisch te bekijken wat goed gaat en waar ze aan kunnen of moeten werken, zij verwerken dit in sterkte-zwakte analyses en reflecties, weergegeven door de groene wolkjes, onder begeleiding van een mentor, met wie op regelmatige basis een gesprek gevoerd wordt, de blauwe vierkantjes. Het doel van het portfolio en de reflecties is het leerproces actief en zelfstandig te sturen. Het portfolio met alle toets en feedbackinformatie en reflecties wordt beoordeeld aan het einde van het jaar, aan deze beoordeling zijn de studiepunten gekoppeld.

Als onderwijsmakers hebben wij hier een aantal lessen geleerd:

1. De veranderingen in het Onderwijs en Examen Reglement mochten pas in $2^{\mathrm{e}}$ instantie doorgevoerd worden, dit waren $\mathrm{mn}$ juridische overwegingen. Dus dit programma van toetsen is volledig geïmplementeerd in 2011 en niet direct bij de start van de opleiding in 2007. De weg ernaar toe en implementatie is zeker ook een proeftuin geweest, die veel heeft opgeleverd. Ik ben blij dat collegae Prof dr Gerard Bos, Dr Roger Rennenberg en Dr Marjan Govaerts de ervaringen van de A$\mathrm{KO}$ opleiding hebben kunnen gebruiken in de herziening van het Master Geneeskunde curriculum in 2013.

2. De bereidheid tot overgave van studenten en docenten van summatieve toetsing zoals 'we dat gewend zijn', naar een programma van toetsen moet niet worden onderschat.

3. Beoordeling van competenties met behulp van een portfolio vergt aandacht. De beoordeling van het portfolio in de A-KO opleiding is ontworpen op geleide van de ervaringen en onderzoek van collega Dr Erik Driessen, waarbij het gebruik van kwalitatieve criteria een portfoliobeoordelingsproces betrouwbaar maakt [33, 34]. Het portfolio wordt verschillende keren bekeken door verschillende mensen, en de informatie die dit geeft, wordt opgebouwd, overgedragen en meegenomen in het beoordelingsproces.

I $k$ benoemde net de transitie van theorie naar praktijk, nu blijkt uit onderzoek dat in de praktijk de transitie van de theorie enigszins anders doorkomt. Ik heb de afgelopen 2 jaar de Master of Health Profession Education. de MHPE, gevolgd. Het is heel verfrissend om zelf weer eens student te zijn en de transitie door te maken van kwantitatief biomedische onderzoek naar kwalitatief onderzoek van onderwijs. Éen van de onderzoeksvragen van mijn MHPE thesis was hoe studenten de invloed 
van een programma van toetsen op hun leergedrag ervaren [35]. Hiervoor zijn A-KO studenten geïnterviewd en de data geanalyseerd, in samenwerking met Drs Andrea oudkerk Pool, Prof dr Lambert Schuwirth, Prof dr Cees van de Vleuten en Dr Erik Driessen. Uit analyse van interview-data bleek dat

1. het programma van toetsen voldoende en bruikbare informatie opleverde voor de studenten.

2. het werd ook duidelijk dat de toetsen werden beschouwd als summatieve, zak-slaag toetsen, in plaats van formatieve informatie. Studenten maakten voor leren voor deze toetsen een inschatting van het (persoonlijk) belang bij de toets en de efficiëntie van de leerresponse. Dit wordt geïllustreerd met deze citatie.

“Ik denk uiteindelijk, in de zin van als je kennistoetsen niet haalt, moet je ze remediëren. Dus in feite bestaat daar een zakken of slagen nog steeds."

Een deel van de oorzaak ligt in implementatie, hoe toetsen en momenten om te remediëren in het onderwijsprogramma zijn gepositioneerd. Een ander deel is hoe studenten, maar ook docenten de toetsen beleven. Terugkijkend is dit misschien niet zo verwonderlijk, toetsen met een cijfer en zak-slaag grens zijn nu eenmaal de norm, en studenten zijn dit gewend vanuit Middelbare school en vooropleiding. Hun leerstrategieën zijn tot nu toe succesvol geweest om door hun studie te navigeren. De perceptie dat toetsen summatief zijn lijkt behoorlijk persistent.

3. Uit de data bleek ook dat feedback van medestudenten werden gezien als formatief en nuttig en dit stuurde de zelfontwikkeling.

4. Het gebruik van alle toets informatie en feedback uit het programma van toetsen voor reflectie in het portfolio werd gezien als zeer nuttig voor leren en zelfontwikkeling. Zoals geïllustreerd met dit citaat.

"vaak denk je dat als je geen portfolio zou hebben, dat je dan gemakkelijker denkt van: oké, leuk, ik heb die feedback gekregen, prima, we stoppen we het weer weg. Maar nu word je wel uitgedaagd om feedback aan elkaar te linken en overeenkomsten te zoeken en ook verschillen en daar over na te denken"

In de interviews waren er ook een paar studenten die het reflecteren moeilijk vonden, of 'over the top', of afleiden van kennis opdoen. Er is onderzoek dat laat zien dat 'reflecteren te leren' is [36]. Ik denk dat in de huidige maatschappij en in het licht van een opleidingcontinuüm het kritisch kunnen nadenken en reflectie over blijvende ontwikkeling onontbeerlijk is. Waarbij de reflectie geen doel op zich moet zijn of 
worden, maar een middel om ontwikkelingsdoelen te stellen en deze op te volgen. Het verzamelen van informatie en reflectie in een portfolio moet voor de student een activiteit zijn die waardevol is en niet iets wat erbij komt of een hoepel op zich. Er is veel aandacht voor blijvende zelfontwikkeling en blijven leren in onze samenleving, bv initiatieven als 'Nederland leert', aparte fondsen voor leraren om zichzelf te blijven scholen en binnen onze eigen instelling.

Een kort intermezzo over kritisch nadenken en jezelf vragen stellen: Op school en in de studie wordt geleerd het juiste antwoord te vinden, wat wordt afgeleerd is dat er soms meerdere antwoorden op dezelfde vraag mogelijk zijn.

Op deze dia (Figuur 5) staan 5 figuren (Roger van Oech). Ik geef U even de tijd om na te denken en te kiezen welke figuur anders is dan alle andere figuren?

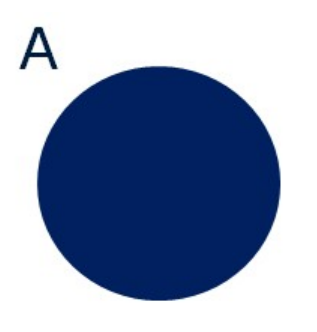

D

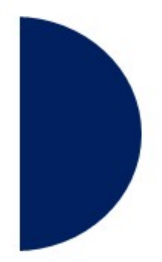

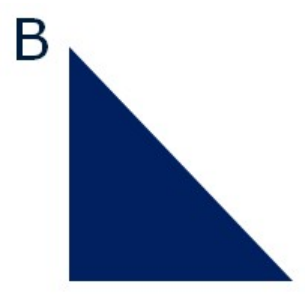

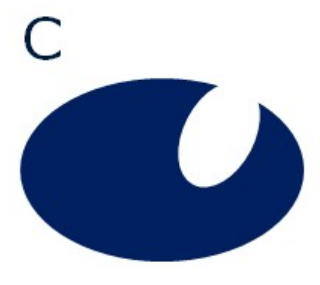

$\mathrm{E}$

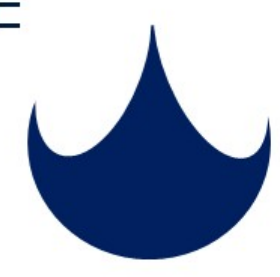

Figuur 5: Figuren van Roger van Oech (www.creativethinking.com)

Had U B gekozen, dat is goed, het is de enige figuur met alleen rechte lijnen.

Maar had U C gekozen, dat is ook goed, het is de enige asymmetrische figuur en wat dacht $U$ van $D$, de enige figuur met zowel rechte lijnen als ronde hoeken.

Waar het hier om gaat: waarom koos $U$ nu voor B en niet voor $C$ ? Er is geen fout antwoord, het antwoord hangt af van de vraag die U Uzelf stelde. En in de context van zelfontwikkeling en reflectie : blijf Uzelf vragen stellen.

Twee belangrijke conclusies uit het onderzoek waren voor mij dat in een constructivistisch onderwijsprogramma met een in theorie 
constructivistisch toetsprogramma, de uitwerking toch reductionistisch kan uitpakken, de toets is een hoepel. Implementatie en persoonlijke overtuiging hoe de toets gewogen wordt zijn belangrijke factoren om rekening mee te houden. Wat implementatie betreft, het is belangrijk om hier kritisch over na te denken, of liever gezegd tijd voor reflectie... Geven de cijfers een te dominant signaal? Moet of kan dat anders? Hoewel de informatie van de toetsen wordt meegenomen in reflectie en studenten hiervan leren, is het begrip 'formatief' en de effecten hiervan op leren nog onvoldoende duidelijk en zeer interessant voor vervolgonderzoek.

Een andere belangrijke conclusie was dat de onderwijskundige impact van het reflecteren op informatie uit een toetsprogramma groot was, hiermee wordt het mogelijk dat de toets een onderwijsmoment wordt, en daarmee toch past binnen de constructivistische gedachte van onderwijs en toetsing.

\section{Deel 4: Toekomst van competentiegericht opleiden en toetsen in de Geneeskunde opleiding in een volgend Raamplan}

Terug naar het Raamplan 2009, de omlooptijd van een Raamplan is ongeveer 8 jaar, wij kunnen (waarschijnlijk) een nieuw Raamplan verwachten rond 2017.

Wat kunnen we verwachten in een nieuw Raamplan?

Het zal weer gebaseerd zijn op een competentie raamwerk, ik verwacht de CanMEDS, hierin meenemend de update die nu plaatsvindt naar de CanMEDS 2015. In de conceptversie van het CanMEDS 2015 document worden een aantal nieuwe competenties of subcompetenties voorgesteld $[37,38]$. Deze nieuwe competenties zijn voorgesteld op basis van een thematische analyse van recente artikelen over competentiegericht onderwijs. Voorgesteld worden (o.a.) : Emotie als competentie, systeem denken, overdracht van zorg, global health en professionele identiteit. Dit laatste is een interessante toevoeging: Wat is professionele identiteit? Professionele identiteit staat naast professioneel gedrag of professionaliteit. Het gaat hierbij om wie je bent, wat vormt wat je bent en hoe je dingen doet. Zoals mooi in het Engels gezegd kan worden 'you are a human being, not a human doing' $[39,40]$. De vorming van dit 'zelf' is continue en hiervoor is reflectie belangrijk, welke vragen stel je jezelf? Deze competentie zou als cirkel om de rozet van de 7 competenties (Figuur 2) worden gepositioneerd en past heel goed bij zelfontwikkeling en constructivistisch competentiegericht opleiden.

Een punt van aandacht hierbij is te inventariseren wat binnen de bestaande competenties en eindtermen mogelijk verdwijnen kan. Zijn de 
eindtermen uit Raamplan 2009 nog steeds relevant, ook voor de Nederlandse context [41], worden deze herkend door de betrokkenen en biedt de werkvloer voldoende aanknopingspunten? Zo merk ik in de portfolio's van de A-KO opleiding dat de competentie 'Maatschappelijk Handelen' niet gemakkelijk herkend wordt en in feedback formulieren en 360 graden feedbackrondes weinig benoemd wordt.

In de conceptversie CanMEDS 2015 zijn ook voor het eerst 'Milestones' opgesteld, van geneeskunde basisopleiding tot praktiserend specialist [37]. Deze milestones komen mogelijk tegemoet aan de vraag van de visitatie commissie Geneeskunde 2011-2012 . In hun State of the Art en Benchmark rapport [42] is de aanbeveling (p34)

“Voor een toekomstig raamplan kan zij zich echter een document voorstellen dat meer houvast biedt voor de opleidingen. Niet zozeer voor de vormgeving van de inhoud van het curriculum, als wel voor de bepaling van de precieze kennis en vaardigheden die van afgestudeerden wordt verwacht, zowel over de basisvakken als de klinische kennis en vaardigheid."

Het kernwoord is hier 'precies'. Hierbij moet gewaakt worden dat de Milestones niet gebruikt gaan worden als een afvinklijst met toetsen per Milestone. De Milestones kunnen (wel) goed gebruikt om het onderwijsprogramma te plannen en tot focus te komen. Voor de toetsing, is constructivistisch toetsen aan te bevelen. Observeer, evalueer kennis, vaardigheden en houding in een authentieke context en geef direct feedback. Doe dit met zoveel mogelijk en zo divers mogelijke evaluatieen toetsinstrumenten, door veel verschillende beoordelaars, met aandacht voor alle lagen van de piramide van Miller, en gebruik geïntegreerde holistische toetsing in een programma van toetsen. De focus zou moeten liggen op ontwikkeling van competenties, mogelijk kan het traject van leerdoelen opstellen, opvolgen en resultaat van het leerdoel, onderdeel uitmaken van de beoordeling.

Het aspect tijd en flexibilisering behoeft ook aandacht, kan de opleiding meer geflexibiliseerd worden? Kan een student de opleiding sneller doorlopen, of het eigen programma meer vormgeven? Dit zijn belangrijke vragen om verder te onderzoeken. Ook gegeven de recente ontwikkelingen rondom het 'schakeljaar' en bezuinigingen in de medische vervolgopleiding. Er wordt nu onderzocht door projectgroepen van de verschillende Faculteiten of competenties verworven in de basisopleiding meegenomen kunnen worden in een verkorting van de vervolgopleiding. De milestones en een 'fit-for-purpose' toegespitst programma van toetsen in de basisopleiding kan hierbij behulpzaam zijn. 


\section{Vijfde deel - Competentiegericht opleiden en toetsen in andere opleidingen van de FHML}

Van de medische opleiding naar andere opleidingen van de FHML: De opleidingen Gezondheidswetenschappen en Biomedische wetenschappen staan voor een belangrijke verandering; de herziening van de bachelors. Voor opleidingen als Biomedische wetenschappen en Gezondheidswetenschappen bestaan geen competentie raamwerken zoals het Raamplan. In het groeidocument 'Herziening bachelors' is er aandacht voor de 'generieke' competenties, die ondergebracht worden in 3 leerlijnen; Academische vorming, praktische vaardigheden, reflectie en professioneel gedrag. In de literatuur gaat het bij 'Generieke competentie' meestal om leerstrategieën, reflectief denken, probleemoplossend vermogen, analytisch vermogen en communicatie $[43,44]$. Ik moet bij de term 'generieke competentie' altijd even schakelen, omdat er in literatuur veel onderzoek is dat aantoont dat competenties specifiek zijn en niet generiek. Bij functioneren in 2 situaties met ongeveer gelijke omstandigheden zou de verwachting zijn dat het functioneren ongeveer gelijk is. Onderzoek laat echter zien dat het functioneren in 1 situatie een slechte voorspeller is voor het functioneren in een andere situatie, zelfs als de situaties veel op elkaar lijken. Dit wordt ook wel 'content-specificity' genoemd [45]. Deze variatie in functioneren in dezelfde competentie in verschillende situaties kan ondervangen worden door programmatisch te toetsen, immers dan zijn er meerdere meetmomenten in meerdere situaties voor bijvoorbeeld de 'generieke' competentie 'probleemoplossend vermogen' en niet 1 enkel moment is doorslaggevend. Dit maakt het mogelijk eenzelfde content-domein, met verschillende evaluatieinstrumenten te bekijken, bv een 360 graden feedback ronde, peerfeedback, feedback van de docent en reflectie op ontwikkeling van de competentie in een portfolio. Ook zijn er dan meerdere aanleidingen voor de student om zichzelf vragen te stellen, "waarom kon ik in deze situatie wel het probleem oplossen en in de andere situatie niet". Qua competenties is de in de CanMEDS 2015 document voorgestelde nieuwe competentie 'professionele identiteit' ook zeer relevant voor de Biomedische wetenschappen en Gezondheidswetenschappen bachelor. De vorming van 'zelf' als 'Biomedisch Wetenschapper', is belangrijk en mogelijk nu onderbelicht. Het kritisch nadenken over wetenschappelijke integriteit past hierbij .

Voor de voorgestelde leerlijnen in het groeidocument liggen goede mogelijkheden voor programmatische toetsing met een constructivistische insteek. 


\section{Afsluiting}

De woorden ballast en bagage zijn in deze rede langsgekomen. Ik denk dat competentiegericht opleiden en toetsen beide in zich heeft, zoals hier op deze dia kort samengevat (Ballast: terugbrengen tot afvinklijsten, reductionistisch toetsen, administratieve olifant. Bagage: reflectie en blijven(d) leren, zelfontwikkeling en constructief opleiden en toetsen). Als onderwijsmakers en coördinatoren is het voor ons de uitdaging deze aspecten mee te nemen in de dagelijkse onderwijspraktijk.

40 jaar geleden begonnen de $1^{\text {ste }}$ studenten Geneeskunde aan deze Faculteit, zij kwamen aan het woord op de opening van het Academisch Jaar 3 weken geleden. Veel van hen kozen bewust voor het nieuwe onderwijssysteem en de opzet van de Geneeskunde studie in Maastricht. Zoals opgemerkt op 1 september en in de Observant, daar was lef voor nodig. De voorzitter van het College van Bestuur, Prof dr Martin Paul roemde die lef: 'Een mooi voorbeeld van de rebelse geest van het begin. Die moeten we vasthouden'. Ik sluit me daar volledig bij aan. Er is ook lef nodig om behavioristische toetsen los te laten en constructivistisch onderwijs te combineren met constructivistisch toetsen, in de verschillende opleidingen van de FHML. De toets als onderwijsmoment. Ik laat daarvoor graag de rebel in mij los. 


\section{Tot slot, Dank}

Mijn dank aan de Stichting Wetenschapsbeoefening UM en het College van Bestuur van de Universiteit Maastricht voor het in mij gestelde vertrouwen en benoeming.

Dank aan Het Toptalenten Programma, een gewaardeerd initiatief van de oud-decaan van de FHML, Prof. dr Martin Paul. Mijn collega's van de ' 2 e lichting' : Ilja Arts, Diana Dolmans, Silvia Evers, Suzanne Frints, Caroline van Heugten, Mirjam oude Egbrink en Matty Wijenberg; Dank voor de goede mix van samen leren en ontspannen.

Dank aan mijn collega's van de afdeling Pathologie onder leiding van Prof dr Axel zur Hausen en de onderzoeksgroep Experimental Vascular Pathology onder leiding van Prof dr Erik Biessen en collega onderzoekers van de Research School CARIM (Cardiovascular Research Institute Maastricht). Het is fijn om een thuishaven te hebben waar een combinatie van onderwijs en onderzoek gewaardeerd en gesteund wordt, veel dank aan mijn promovendi voor de wederzijdse leerweg, en alle vroegere en huidige collega's.

Dank aan Marianne Quaden voor alle hulp rondom deze dag.

Dank aan de collega's van de afdeling Onderwijsontwikkeling en Onderwijsresearch en de SHE Graduate school, onder leiding van Dr Erik Driessen en Prof dr Cees van de Vleuten. ik waardeer het zeer om betrokken te worden en zijn bij onderwijsprojecten, ik leer hier steeds meer.

Dank aan de docenten en staf van de Arts-Klinisch Onderzoeker Masteropleiding en collega's van het Onderwijsinstituut. Ik heb bewondering voor jullie betrokkenheid en inzet in deze opleiding, de A-KO heeft soms net wat andere roosters, toetsprogramma en SAP structuur, en dit vraagt wat creativiteit om te voorkomen dat het systeem het onderwijs en de toetsing dicteert. Speciaal woord van dank voor de studenten, voor jullie enthousiasme, en feedback.

Lieve familie en vrienden, wat fijn dat jullie hier zijn, dank voor jullie belangstelling en komst. Lieve mama, Peter en Sandra, in blijvende herinnering mijn vader, en schoonouders AnnaMaria en Jan, dank voor jullie vertrouwen, liefde en draagkracht. Jons, Alijt en Gebbe, jullie zijn mijn kern. 
I $k$ wil afsluiten met dit citaat: 'De werkelijke regisseur van ons leven is het toeval - een regisseur vol wreedheid, barmhartigheid en verrassende charme', van de Portugese arts Amadeu de Prado in het boek 'Nachttrein naar Lissabon'.

Ik zie de charme van het toeval in een carrière die mij van biomedisch onderzoeker naar bijzonder hoogleraar in onderwijs heeft gebracht. Wij voelen ook het verdriet van de wreedheid van het toeval door het verlies van onze zoon Gebbe, 4 jaar geleden, hij is 15 jaar geworden. Het feestelijke en bijzondere van vandaag staat tegenover geliefden die worden gemist. Die twee kanten vandaag te ervaren met mensen om ons heen, is waardevol, dank dat jullie er zijn.

Ik heb gezegd. 


\section{Referenties}

1. Van Merriënboer, J.J., M.R. Klink, and M. Hendriks, Competenties: van complicaties tot compromis: over schuifjes en begrenzers. 2002: Onderwijsraad Den Haag, the Netherlands.

2. Ertmer, P.A. and T.J. Newby, Behaviorism, cognitivism, constructivism: Comparing critical features from an instructional design perspective. Performance improvement quarterly, 1993. 6: p. 50-72.

3. Cooper, P.A., Paradigm Shifts in Designed Instruction: From Behaviorism to Cognitivism to Constructivism. Educational technology, 1993. 33: p. 12-19.

4. Simons, P.R.-J., Competentiegericht leeromgevingen in organisaties en hoger beroepsonderwijs, in Competentiegerichte leeromgeving, K. Schlusmans, et al., Editors. 1999, Uitgeverij Lemma BV.: Utrecht. p. 31-45.

5. Morcke, A., T. Dornan, and B. Eika, Outcome (competency) based education: An exploration of its origins, theoretical basis, and empirical evidence. Advances in health sciences education, 2013. 18: p. 851-863.

6. Van der Klink, M., J. Boon, and K. Schlusmans, Competenties en beroepsgericht hoger onderwijs: Stand van zaken en toekomstperspectief [Competences and vocational higher education: Now and in future]. Eur J Voc Training, 2007. 30: p. 67-82.

7. Malone, K. and S. Supri, A critical time for medical education: the perils of competence-based reform of the curriculum. Advances in health sciences education, 2012. 17: p. 241-246.

8. Korthagen, F., Zin en onzin van competentiegericht opleiden. VELON Tijdschrift voor, 2004.

9. Delandshere, G. and A.R. Petrosky, Assessment of complex performances: Limitations of key measurement assumptions. Educational Researcher, 1998: p. 14-24.

10. Lurie, S., C. Mooney, and J. Lyness, Commentary: pitfalls in assessment of competency-based educational objectives. Academic Medicine, 2011. 86: p. 412-414.

11. Norman, G., J. Norcini, and G. Bordage, Competency-Based Education: Milestones or Millstones 1? Journal of graduate medical education, 2014. 6: p. 1-6.

12. van Rossum, H., Medisch onderwijs in Nederland, 1972-2012, in Gezonderwijs in Nederland en Vlaanderen. 2013, Springer. p. 35-47.

13. Miller, G., E., The assessment of clinical skills/competence/performance. Academic Medicine, 1990. 65: p. S63-7.

14. Interfacultair-Overleg-der-Nederlandse-Faculteiten-der-Geneeskunde, Raamplan 1974. Medisch Contact, 1974. 32: p. 1017-1021.

15. Schade, E. and T. Sminia, Eindtermen voor de universitaire artsopleiding:Raamplan 1994 artsopleiding. Nederlands tijdschrift voor geneeskunde, 1995. 139: p. 30-30.

16. Metz, J., A. Verbeek-Weel, and H. Huisjes, Raamplan 2001 artsopleiding: bijgestelde eindtermen van de artsopleiding. 2001.

17. van Herwaarden, C., R. Laan, and R. Leunissen, The 2009 Framework for Undergraduate Medical Education in the Netherlands. http://www.vsnu.nl/Mediaitem/Raamplan-Artsopleiding-2009.htm, 2009.

18. Frank, J.R. and (Ed), The CanMEDS 2005 physician competency framework. Better Standards. Better Psysicians. Better Care. 2005, The Royal College of Physicians and Surgeons of Canada: Ottawa.

19. Biggs, J., Aligning teaching for constructing learning. Higher Education Academy, 2003.

20. Schuwirth, L. and C. van der Vleuten, Competentiegerichte toetsing in het klinisch onderwijs. Nederlands tijdschrift voor geneeskunde, 2005. 149: p. 2752. 
21. Cilliers, F.J., L. Schuwirth, N. Herman, H.J. Adendorff, and C.P.M. van der Vleuten, $A$ model of the pre-assessment learning effects of summative assessment in medical education. Advances in health sciences education, 2012. 17: p. 39-53.

22. Dochy, F., M. Segers, D. Gijbels, and K. Struyven, Assessment engineering, in Rethinking assessment in higher education: learning for the longer term, D. Boud and N. Falchikov, Editors. 2007, Routledge: Oxford. p. 87-100.

23. Wass, V., C. van der Vleuten, J. Shatzer, and R. Jones, Assessment of clinical competence. The Lancet, 2001. 357: p. 945-949.

24. Driessen, E., J. van Tartwijk, J. Vermunt, and C. van der Vleuten, Use of portfolios in early undergraduate medical training. Medical teacher, 2003. 25: p. 18-23.

25. Friedman Ben David, M., M.H. Davis, R.M. Harden, P.W. Howie, J. Ker, and M.J. Pippard, AMEE Medical Education Guide No. 24: Portfolios as a method of student assessment. Medical teacher, 2001. 23: p. 535-551.

26. Tillema, H., Portfolios as developmental assessment tools. International Journal of Training and Development, 2001. 5: p. 126-135.

27. van Tartwijk, J. and E. Driessen, Portfolios for assessment and learning: AMEE Guide no. 45. Medical teacher, 2009. 31: p. 790-801.

28. Schuwirth, L. and C. van der Vleuten, Programmatic assessment: From assessment of learning to assessment for learning. Medical teacher, 2011. 33: p. 478-485.

29. van der Vleuten, C. and L. Schuwirth, Assessing professional competence: from methods to programmes. Medical education, 2005. 39: p. 309-317.

30. van der Vleuten, C. and L. Schuwirth, Een model voor programmatisch toetsen. Examens 2011. 3: p. 5-9.

31. van der Vleuten, C., L. Schuwirth, E. Driessen, J. Dijkstra, D. Tigelaar, L. Baartman, and J. van Tartwijk, A model for programmatic assessment fit for purpose. Medical teacher, 2012. 34: p. 205-214.

32. Schuwirth, L. and J. Ash, Assessing tomorrow's learners: In competency-based education only a radically different holistic method of assessment will work. Six things we could forget. Medical teacher, 2013. 35: p. 555-559.

33. Driessen, E., K. Overeem, J. van Tartwijk, C. van der Vleuten, and A. Muijtjens, Validity of portfolio assessment: which qualities determine ratings? Medical education, 2006. 40: p. 862-866.

34. Driessen, E., C. van der Vleuten, L. Schuwirth, J. van Tartwijk, and J. Vermunt, The use of qualitative research criteria for portfolio assessment as an alternative to reliability evaluation: a case study. Medical education, 2005. 39: p. 214-220.

35. Heeneman, S., A. oudkerk Pool, L. Schuwirth, C. van der Vleuten, and E. Driessen, Students as active constructors of their learning while assessing at the program level. Submitted for publication, 2014.

36. Masui, $\mathrm{C}$. and $\mathrm{E}$. Corte, Learning to reflect and to attribute constructively as basic components of self-regulated learning. British Journal of Educational Psychology, 2005. 75: p. 351-372.

37. Frank, J. and L. Snell, The Draft CanMEDS 2015 Physician Competency Framework. Ottawa: Royal College of Physicians and Surgeons of Canada, 2014.

38. Van Melle, E., A New and Emerging Concepts as Related to the CanMEDS Roles Overview. www.royalcollege.ca, 2014.

39. Goldie, J., The formation of professional identity in medical students: Considerations for educators. Medical Teacher, 2012. 34: p. e641-e648.

40. Monrouxe, L., Negotiating professional identities: dominant and contesting narratives in medical students - longitudinal audio diaries. Current Narratives, 2009. 1: p. 41-59. 


\section{Oratie Prof. dr. Sylvia Heeneman}

41. Ringsted, C., T. Hansen, D. Davis, and A. Scherpbier, Are some of the challenging aspects of the CanMEDS roles valid outside Canada? Medical education, 2006. 40: p. 807-815.

42. QANU, Geneeskunde Onderwijs in Nederland 2012, State of the Art Rapport en Benchmark rapport van de visitatiecommissie Geneeskunde 2011-2012. 2012.

43. Heijke, H., C. Meng, and C. Ris, Fitting to the job: the role of generic and vocational competencies in adjustment and performance. Labour economics, 2003. 10: p. 215229.

44. Nikolaou, I., The development and validation of a measure of generic work competencies. International Journal of Testing, 2003. 3: p. 309-319.

45. Eva, K., On the generality of specificity. Medical education, 2003. 37: p. 587-588. 